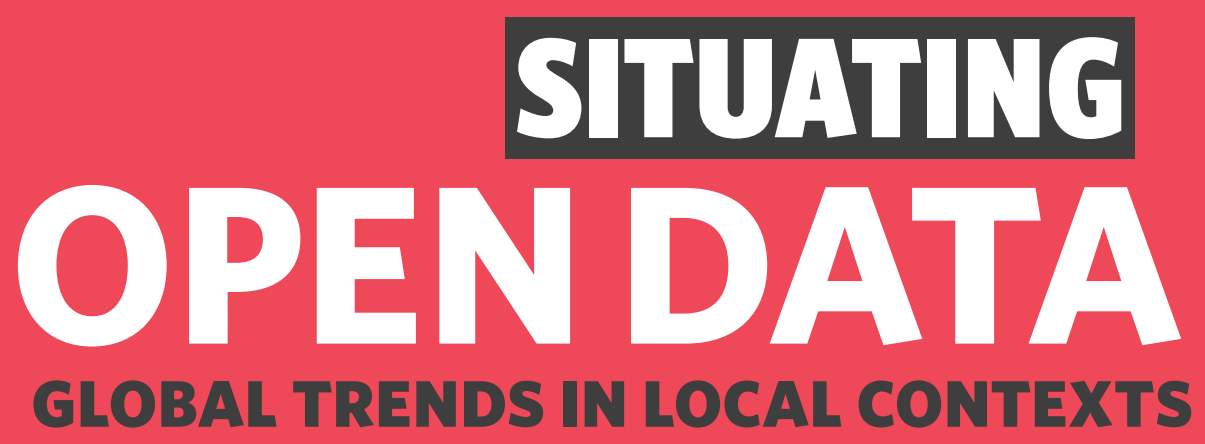

Edited by Danny Lämmerhirt, Ana Brandusescu, Natalia Domagala \& Patrick Enaholo 


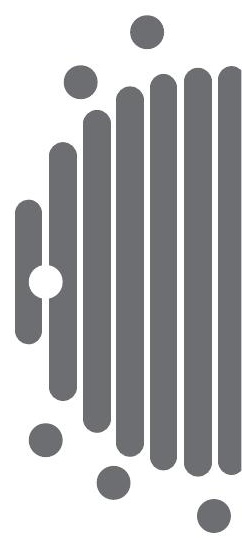

\section{Situating Open Data Global Trends in Local Contexts}

Edited by

Danny Lämmerhirt, Ana Brandusescu, Natalia Domagala \& Patrick Enaholo 
Published in 2020 by African Minds

4 Eccleston Place, Somerset West 7130, Cape Town, South Africa

info@africanminds.org.za

www.africanminds.org.za

This work is published under a Creative Commons Attribution 4.0 International License (CC-BY).

ISBN Paper 978-1-928502-12-8

ISBN eBook 978-1-928502-13-5

ISBN ePub 978-1-928502-14-2

Orders:

African Minds

4 Eccleston Place, Somerset West 7130, Cape Town, South Africa

info@africanminds.org.za

www.africanminds.org.za

For orders from outside South Africa:

African Books Collective

PO Box 721, Oxford OX1 9EN, UK

orders@africanbookscollective.com

www.africanbookscollective.com 


\title{
Closing the gaps in open data implementation at sub-national government level in Indonesia
}

\author{
Ilham Cendekia Srimarga \& Markus Christian
}

Given the rapid development of information technology for the past fifteen years, there are people in various quarters who believe that this has spurred wider adoption of an open ICT ecosystem. ${ }^{1}$ Such an ecosystem is believed to be instrumental in transforming (especially) developing countries in reaching their development goals. ${ }^{2}$ With that belief, many governments (national and local) have opted to adopt open ICT ecosystems to overcome their development challenges.

Nevertheless, there have been questions whether ICT projects have the intended impact. Research was conducted 'to understand the impact of open data projects in terms of changes in the relationship between an intermediary organisation and a data supplier (government), and between the intermediary and the end-user' (Maail 2017: 153). The study presented in this chapter is of a kind that applies the action research approach (direct involvement of the researcher-participant in changing the research subject) by looking at the process of open data conception and implementation in a district and how the response dynamics took shape.

The approach considered the combination of the local specific needs and the generic and replicable data design to show that there is a significant mutual shaping between local needs and the ICT design put forward by the technology designers (see Orlikowski 1992; Diniz et al. 2014).

1 'An ICT ecosystem encompasses the policies, strategies, processes, information, technologies, applications and stakeholders that together make up a technology environment for a country, government or an enterprise' (Open ePolicy Group 2005: 3).

2 Smith M \& Laurent E (2010) Open ICT ecosystems transforming the developing world. Information Technologies and International Development 6 (1): 65-71. 
The study was carried out in Bojonegoro, Indonesia, a district that actively builds innovation, develops open government and promotes good governance, particularly since 2014. ICT utilisation for addressing development problems is one of the policy priorities of Bojonegoro district government. At that time, the regent (or mayor) of Bojonegoro district, Suyoto, believed that open and innovative government is a road the district must take to achieve its local development goals, particularly as part of its improvement in education and health as well as poverty eradication. He also believed that open government means involving the community to reach the development targets.

One of government's openness strategies is open data. In this context, open data was translated as the provision of data that is open to all actors, both state and non-state actors (such as NGOs, CSOs, community-based and faithbased organisations). Open data is expected to allow state and non-state actors to access and immediately use the data to contribute to achieving the local development goals of Bojonegoro. Some of the main goals of local development are, for example, reducing poverty, increasing enrolment rate, improving access to health services, and improving infrastructure.

The government of Bojonegoro implemented open data to facilitate its open policy. The open data implementation has two phases. In the first phase, the district government implemented it single-handedly. Some activities were (1) opening up public data to the citizens in the district; (2) collaborating with the central government, that is the $\mathrm{UKP}^{3}$ (now presidential staff office or KSP), to implement One Data system; and (3) conducting public dialogues regularly in which data is opened up to the participants (the public/citizens).

The Bojonegoro government utilised its web portal as the channel for opening up the data to the public. However, the data was still in aggregated format and mostly not up to date. The data displayed was not comprehensive and in a format that was difficult to process. On the other hand, the demand for data was still low. The citizens and communities still failed to comprehend the data and did not have the capacity to use and benefit from the opened data.

Since the results of the first phase of open data implementation were considered as below expectation, the Bojonegoro government decided to introduce improvement. They took the second phase of open data implementation in which the government welcomed cooperation with various stakeholders, especially CSOs. These CSOs were expected to provide analyses and recommendations on the open data implementation in the district. The space given by the government motivated Sinergantara to get involved by introducing the idea of 'data revolution' in Bojonegoro.

3 UKP4 stands for Unit Kerja Presiden Bidang Pengawasan dan Pengendalian Pembangunan, set up primarily to monitor ministries and central government agencies' works and to ensure acceleration of government programmes. It was formed under the administration of President Susilo Bambang Yudhoyono (2009-2014) and now replaced by KSP (Kantor Staf Presiden). 
The involvement of Sinergantara and other CSOs in identifying the problems, conceiving the solution and implementing it, as well as the temporary changes produced by the implemented solution, is the subject of the action research presented in this chapter.

The research questions posed by the research are as follows:

1. What are the factors or issues that may lead to disconnections ${ }^{4}$ (gaps) in open data implementation at the sub-national level (in this case, in Bojonegoro district, Indonesia), in relation to the government's expectations on the contribution of open data to efforts of achieving local development goals?

2. What are the 'closing the gaps' solutions developed by Bojonegoro district government, and what are the processes and background that led to the solution? How does collaboration of sub-national governments and non-state actors contribute to the birth of the solution?

3. How does the implementation of the solution help improve effectiveness of open data at the sub-national level? What has been changed, particularly among the actors involved in the open data implementation? (Changes at target groups/beneficiaries which may not be visible at the moment.)

4. What are lessons that can be drawn from the experience of open data implementation in Bojonegoro district (from identification of disconnection/gaps to implementation of solutions for closing the gaps) for knowledge on open data implementation at the sub-national level in other areas?

The objectives of the research are

1. To describe the lessons drawn from the experience of Bojonegoro district government (sub-national government) in Indonesia with regard to:

a. identification of obstacles that led to disconnection/problems in their open data initiative implementation;

b. development of solutions that allow the realisation of open data to support the efforts of achieving their local development goals;

c. utilisation of disaggregated data (single data) for solving problems that usually create gaps in open data initiative implementation.

4 In our understanding, there are several types of disconnection: (1) disconnection due to physical distance; (2) disconnection due to nonexistent communication; (3) disconnection due to limited capacity of the beneficiaries; (4) disconnection resulting from complexity of reference/information coming from the supply-side (open data provider); (5) disconnection due to management aspects; (6) disconnection due to limited (or unavailable) space for participation; and (7) disconnection due to unavailable information. The issues raised in this paper are connected to points $3,4,5$. 
2. To explain possible impacts (or potential impacts expected to happen in the near future) as a result of the innovation in Bojonegoro district. This chapter will look at these impacts from two sides: (1) benefit of open data innovation to the efforts of achieving local development targets; (2) contribution of this solution of innovation to the maturity of open data approaches at sub-national government level.

\section{Methods}

Research that underlies this chapter is action research, in which the researcher (author) is involved in the interventions or efforts of making this initiative work during implementation. The author of the chapter acts as a researcherparticipant, getting involved in the process of providing solution(s) as well as the implementation (Kemmis, McTaggart \& Nixon 2014; McNiff \& Whitehead 2002).

The researcher took four steps in the research: (a) assessment; (b) intervention; (c) observation; and (d) reflection. These steps are modified from the standard steps of action research. ${ }^{5}$

\section{Assessment}

Several steps were taken as part of the assessment, which aimed to review the existing situation in order to develop the next steps of the action research:

- Understanding the ecosystem of the open data initiative implementation in Bojonegoro district. By the ecosystem of open data, we mean a set of relationships consisting of actors, relations among actors, artefacts, relation between actor and artefact and how the situation influences open data initiative implementation (whether it supports, inhibits, or distracts).

- Identifying the business processes of the ecosystem. In this case, we see what business processes (activities) occur within the open data implementation and the progress they make (smoothness of the activity's workflow).

- Understanding critical points that result in obstacles inhibiting the activity flow. On these points, obstacles came from various factors leading to the situation that we call disconnection (gap).

- Understanding of the gap as illustrated by the visual scheme which makes people understand which points suffer gap/disconnection.

5 Most action research consists of standard cyclical steps comprised of: (a) planning; (b) action; (c) observing; (d) reflecting (see McNiff \& Whitehead 2002). As there is the element of participation of the researcher, we also refer to Kindon et al. (2007). 


\section{Intervention}

After identifying the situation, the researcher devised interventions to help solve the problem. Basically, the interventions consisted of actions to identify the gaps of the first open data implementation in Bojonegoro and actions to develop a solution to address the problem.

Several activities were conducted to enable the author to gain insight into the gaps and or problems affecting the first process of open data implementation in Bojonegoro: (1) Interviews with various stakeholders on existing issues of open data implementation in the district. The interviews were in the form of focus group discussions (FGDs) and face-to-face meetings. (2) Close engagement with the then regent of Bojonegoro, Mr Suyoto (also well known as Kang Yoto). Kang Yoto expressed his strong interest in developing and adopting open data in his district and shared many of his ideas about the issue. It was the regent who provided support to the development and implementation of the solution.

To complement the above activities, the researcher also carried out desk study and consultation with the staff of the government of Bojonegoro concerning the existing and yet-to-be developed regulation on open data implementation in the district. The researcher also studied the technological system (including technical elements) of the open data in Bojonegoro as employed in the first phase of the programme. Critical focus is directed toward the way data is collected, stored and processed.

Since open data requires participation and the solution must also involve this aspect, the researcher then engaged with local CSOs to get insight about the view and perspective of the demand side regarding the open data implementation in the district.

Having all the needed information and insight on the obstacles and other inhibiting issues of the first process of open data implementation in Bojonegoro, the author and his organisation conducted solution-related intervention.

The first was the inventory and identification of the existing solutions (that have been developed) by state and/or non-state actors. The researcher looked into what has been done to address the issues and bridge the gaps. Afterward, the researcher conducted further elaboration by seeking agreement from the government and CSOs on what kind of solution the district needed.

Those two activities became the basis of developing a solution in which the researcher and his organisation conducted the following:

- Developing 'data revolution' methodology consisting of: (i) development of manual on data revolution methodology; (ii) development of Androidbased Revo-application installed on smartphones and desktop-based dashboard to store and process the data collected from the application.

- Conducting participatory data collection using the application. The data was stored and processed in the desktop. Some volunteers in certain 
selected villages in Bojonegoro applied the methodology by using the app and allowed the collection of basic data to be stored in the system.

- Providing training and short education courses regarding the data revolution methodology by involving government staff and volunteers from the villages.

\section{Observation}

Parallel with and after the intervention, the researcher conducted observations. As the study was an instance of participatory action research, the researcher had been actively engaged with other stakeholders and directly involved with the implementation of the solution that he and his organisation devised. At the same time, the researcher took a distance and looked at the ongoing process from the 'outside'. This was intended as a means to monitor and record the process in order to generate the data.

Two issues became the framework for conducting observation:

- The process of translating the interest of the regent into a technological system (open data system): The researcher came forward with the solution to the problem of the first process of open data implementation by developing a technological system (application and dashboard). The question was how this technology was received by and the response of the stakeholders (supplier of data within the government and the users among the citizens/CSOs).

- The second open data implementation developed a new kind of data, one of which is the social data consisting of individual and household data representing the timely condition of each individual and family as well as certain conditions (like high-risk pregnant mothers and those living in poverty). How has the social data been received, responded to, and adopted by the stakeholders?

\section{Reflection}

Reflection was the next step following action and observation in action research. Reflection is based on the data collected during the action phase in which the author conducted various activities to introduce the solution to the existing situation. Reflection is also a backward-forward look in action research. It is backward as it looks at the action already taken, while it is also a look forward since the result of the reflection will become the basis for the next action research (or just action).

The focus of the author of this chapter in reflection has been on the possible change that already happened due to the introduction of the solution (data revolution) to the open data implementation in Bojonegoro. Several issues were reflected on based on the data collected during the action: 
a. Impacts of effectiveness of implementation. The author looked at the following aspects and reflected upon the changes that may occur:

- Sub-national government policies related to this initiative.

- Sub-national government's work plan related to implementation of this initiative.

- Budget availability of sub-national government and CSOs related to implementation of this initiative.

- Availability of work team from government side and CSO to support implementation of this initiative.

- Progress of (work) implementation of the initiative.

b. The closing of the disconnection by the implemented solution. By looking at the problems related to the disconnection; whether they had been addressed or not by the solution. Here, the author reflected whether the solution already addressed the following problems:

- Late update of available data.

- Difficulty in processing the open data ${ }^{6}$ provided.

- Difficulty in verification of the open data provided.

- Inconsistency between open data that is provided and data that is needed.

\section{Findings}

This research began with the assessment phase in which the researcher identified the issues and possible problems in the subject of the research, which was the first phase of open data implementation (or the first process) in Bojonegoro district. It was found that the district government had a certain assumption about open data, and it led to the way the implementation was carried out.

Figure 1 below explains what the regent of Bojonegoro expected from open data and the collaboration of state and non-state actors.

First, it was assumed by the regent and the staff of Bojonegoro district that the existence of open data allows state and non-state actors to find and have better information sources, so that they can contribute more actively in achieving local development goals. Second, they assumed that the actors have developed the habit (familiarity) and ability of using or processing data (in all formats) into specific information that can be immediately used to contribute to achieving local development goals. Third, it was assumed that in terms of quality, open data has certain sufficiency and comprehensiveness that allows them to be processed into the desired information.

6 Here, 'open data' is understood as data already integrated into open data system, and digitised version of GDCS (Gerakan Desa Cerdas dan Sehat / Healthy and Smart Village Movement) data. This GDCS data was collected manually by village volunteers in Bojonegoro. 
Figure 1. Expectation and assumption of how open data initiative is implemented

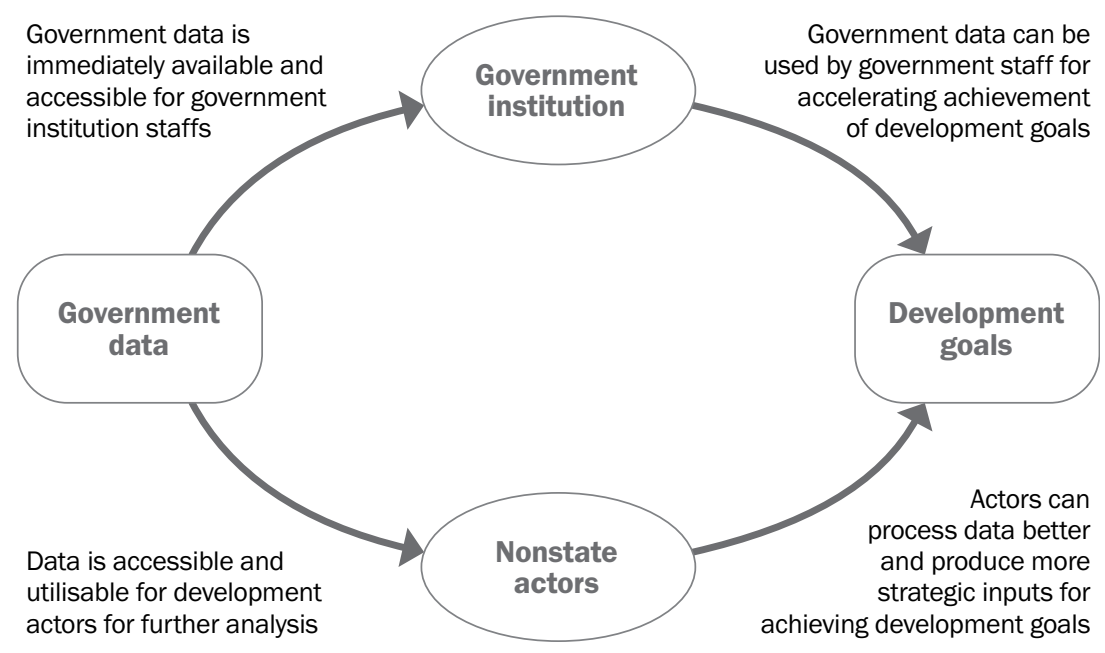

These assumptions were based on the knowledge of the regent of the importance of open data for development. Especially in regard to the first assumption, the regent was inspired by the thinking of Jeffrey Sachs (2015 a, b). Data is considered as vital to development and for data to be instrumental it should be open and accessible. The regent's thinking was also sparked by the newly implemented (at the time) freedom of public information act (Undang-undang Keterbukaan Informasi Publik Nomor 14 Tahun 2008). ${ }^{7}$ In its implementation, the law only required the government to publish its information to make it accessible to the public. With that, the government was considered as innovative without having seen the real impact of the implementation to local development.

However, during the implementation of open data, some obstacles (disconnection or gap between what is expected and what actually happened) were found that made the utilisation process of open data fall short of expectations. Figure 2 visualises the obstacles found. The obstacles are related to quality of data and its attendant consequences.

The lack of quality of the open data makes state and non-state actors find it difficult to use and process the published data (data made accessible to the public) into more significant information that can contribute to the efforts of achieving local development goals. We conform to the definition of data quality as 'the degree to which a set of characteristics of data fulfils requirements. Examples of characteristics are: completeness, validity, accuracy, consistency, availability and timeliness. Requirements are defined as the need or expectation that is stated,

7 The law was passed in 2008 and it took effect in 2010. 
generally implied or obligatory'. ${ }^{8}$ For example, the first process of open data provided only the manual data which was then published on the web, bringing with it the characteristic of the 'old' data, which was aggregated, not up to date, thus inaccurate and not valid (as it was too obsolete and incomplete). ${ }^{9}$

Consequently, the lack of data quality led to less than effective openness; local actors have access to data but still find it challenging to really use the data. It was further prohibited by the discrepancy between available data (data provided) and their need for data. Thus, data utilisation by local actors in supporting local development goal achievement is far below expectation. Unfamiliarity with the data among the actors and the lack of quality of the data together make it difficult for the actors to contribute to the efforts of achieving local development goals.

Figure 2. Diagram of problems in open data initiative implementation

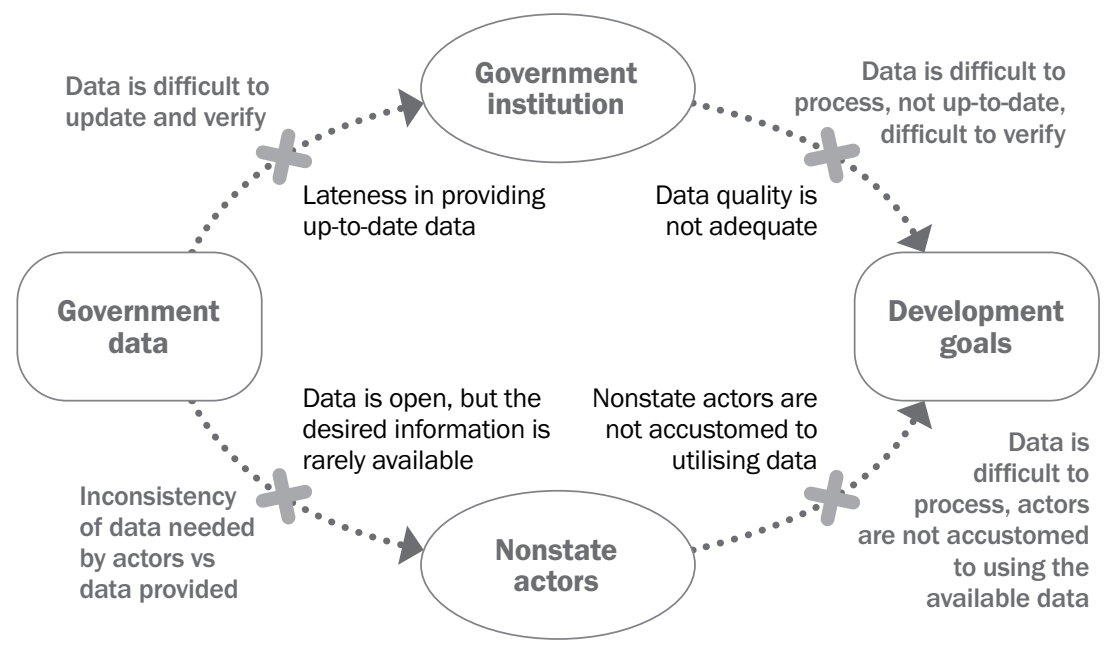

Put simply, problems related to the open data initiative in Bojonegoro district are low quality of data and low capacity (or familiarity) of local actors in using the data effectively. After a series of FGD activities with stakeholders, we found factors contributing to both problems were data update and data verification processes that do not occur immediately (or usually lagging) in the district. Also, the available data (which is in aggregated format only) is difficult to process as

8 This definition from Wikipedia is just one of many definitions and it is related to the ISO 9000 definition of quality. As to the issues of data quality, see Redman TC (2008) Data Driven: Profiting from Your Most Important Business Asset. Boston: Harvard Business Press. p. 41.

9 Data on schools, for example, only shows the aggregate number without providing details of each school (the single data). The data is the result of a survey conducted one year past at the latest and/or even earlier than that (two to three years past). 
well as it does not suit the needs of local actors. The root of these problems is the unavailability of disaggregated data.

Some of the main reasons for the problems are illustrated in Figure 3.

Figure 3. Logic structure of root of open data innovation problem in district government

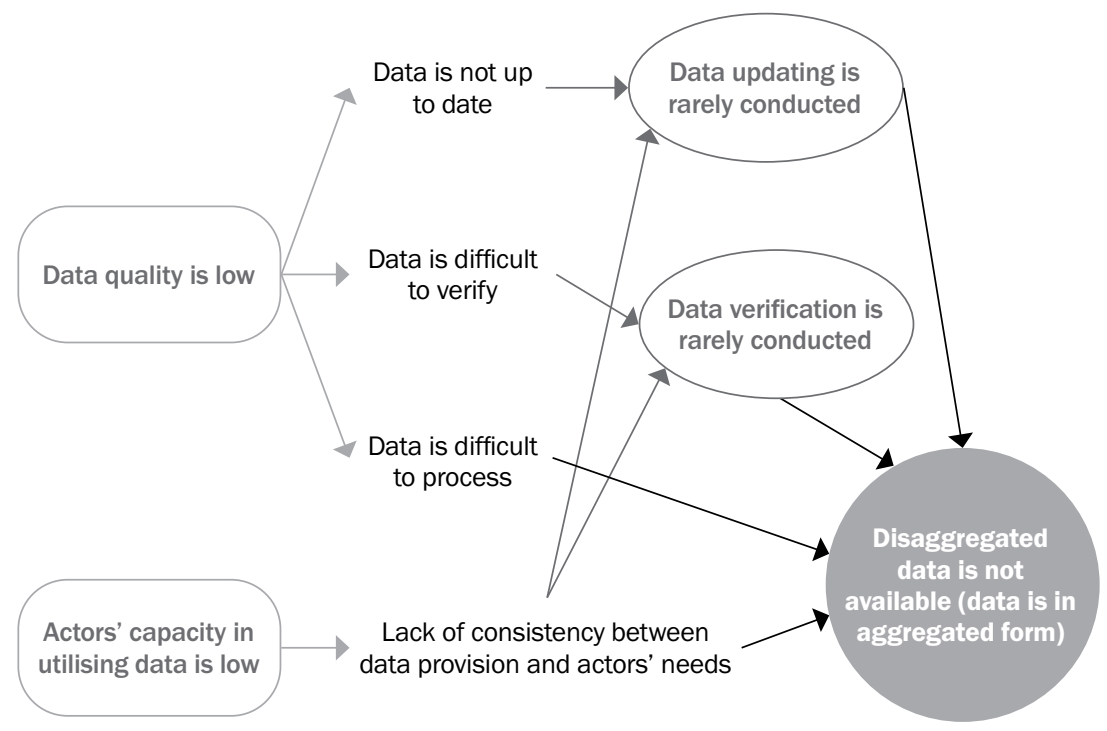

The regent of Bojonegoro saw the problem and thought of ways to overcome it. He then invited CSOs to analyse the situation and provide the government with the possible solution. It is here that the researcher started to be a participant in the development of a solution and introduced the idea of 'data revolution'. The regent entertained the idea and provided support for its adoption. He then decided to initiate data revolution which contains systemic efforts of improving data quality, availability, and update. The data revolution is implemented through, among many efforts, providing disaggregated data (or single data) that is also called data at zero level. Data at that level can be used to monitor the situation of the population of the district, whether it is the individual or the family. Using data at zero level, data update and verification processes can be conducted more easily and quickly.

The regent of Bojonegoro thought the idea would suit the situation of Bojonegoro district at that time. The district government had already had a data collection routine which is conducted regularly throughout the whole year. The activity, called 'Dasa Wisma' data collection (data per 10 households, collected by each neighbourhood), has produced data per individual citizen and per family of each village which is updated every 6 months. The data is in disaggregated 
form. By applying aggregation and analysis, the district government considered the data as instrumental in measuring development achievements and providing early warning. However, until 2016, the data was available only in manual/ non-digital format, and the structure still needed improvement to allow it to be processed further.

In 2016, data revolution ${ }^{10}$ and open data contract initiative was included as part of the sub-national Open Government Initiative (OGP) of Bojonegoro district government. ${ }^{11}$ This was like the second launching of open data for Bojonegoro government, after the open data initiative in 2014.

Following the second launching of open data in September 2017, there were several steps that the researcher-participant took. The first was the development of technology, especially for the purpose of data structuring and digitising. The researcher-participant created a data revolution application aimed at ensuring the quality, availability and update of data. The second was the involvement of the citizens from the very beginning of the process through their active participation in single data (disaggregated data) collection. This participation allowed the citizen to have a first-hand experience of being involved in developing disaggregated data. It also resulted in their understanding of the benefit of disaggregated data and the usability of such data for local development.

Both steps resulted in a data format that suits the data revolution approach: well-structured and processable digital data which is regularly updated. The digital data is made possible by technology (IT application), while the regular updating is facilitated by government-sanctioned citizen participation. Figure 4 shows how the data has undergone digitisation as vital steps in the implementation of the open data (the second process).

Figure 4. Steps in relation to data in data revolution (Second Process)

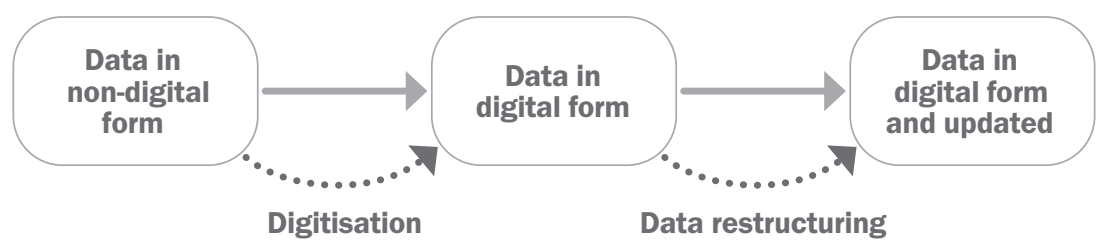

10 The data revolution conducted in Bojonegoro district is an activity that consists of: (1) digitalisation of datasets on citizens and households (families) in all villages of Bojonegoro district; (2) providing additional information of geospatial location and photographs of every family by geo-tagging and using application on smartphone; and (3) providing access to citizen organisations at sub-village level to update individual data (citizen and family data) on their sub-district that represents actual change that occurs to individual citizens or families.

11 Bojonegoro district is selected as one of 14 sub-national governments participating in OGP pilot projects. 
Table 1. Comparison between open data 1 and open data 2

\begin{tabular}{l|l|l}
\hline Format & $\begin{array}{l}\text { The first (early) } \\
\text { open data initiative }\end{array}$ & $\begin{array}{l}\text { The second (follow-up) } \\
\text { open data initiative }\end{array}$ \\
\hline $\begin{array}{l}\text { in the national open data website } \\
\text { (government website). By opening } \\
\text { and sharing the data to the public, the } \\
\text { government expected that the public } \\
\text { would respond and use the data. }\end{array}$ & $\begin{array}{l}\text { Data revolution: digitisation of single } \\
\text { data, adding geo-tagging information and } \\
\text { photos, collecting, storing, and processing } \\
\text { data in the single (disaggregated) format. }\end{array}$ \\
$\begin{array}{l}\text { Open data contract: publication of } \\
\text { Stakeholder } \\
\text { involvement }\end{array}$ & $\begin{array}{l}\text { The regent, the staff of the central } \\
\text { government, the staff of the local } \\
\text { government (especially the heads of the } \\
\text { local agencies) }\end{array}$ & $\begin{array}{l}\text { processing of project's data in single } \\
\text { data format. }\end{array}$ \\
\hline $\begin{array}{l}\text { Which data } \\
\text { is opened }\end{array}$ & $\begin{array}{l}\text { All data available in government data } \\
\text { centres, regardless of whether the data } \\
\text { is updated or not. The data is mostly } \\
\text { represented as aggregate. }\end{array}$ & $\begin{array}{l}\text { The data which is collected with the } \\
\text { participation of citizens in the form of } \\
\text { single data and it is updated regularly } \\
\text { based on citizen reporting. }\end{array}$ \\
\hline $\begin{array}{l}\text { Expected } \\
\text { data } \\
\text { utilisation }\end{array}$ & $\begin{array}{l}\text { The government (or other agencies) and } \\
\text { the citizens/ communities are expected } \\
\text { to use the data as their references. }\end{array}$ & $\begin{array}{l}\text { The government (or other agencies) and } \\
\text { the citizens/communities are expected } \\
\text { to use the data for further process into } \\
\text { information that they need. }\end{array}$ \\
\hline
\end{tabular}

One of the important points in data revolution is related to the fact that data updating can be done immediately and the fact that the citizens can participate in data updating. Immediate and participatory updating are made possible because data revolution is about management and processing of data in a single (disaggregated) format. As explained above, the single data format allowed the updating and verification process to be applied to single individuals and households. On the other hand, the aggregated format, which is currently available in the local government data system, limits the management and updating process. Consequently, the utilisation of such aggregated data is also limited to being just a reference (without further processing according to the specific needs of the users).

\section{Single data}

To get a sense of what single data means, see representations of two data below, namely local poverty data (table of aggregated data) and family data (table of single data). 
Table A: Local Poverty Data

\begin{tabular}{l|c|c|c}
\hline Name of Village & $\begin{array}{c}\text { Number of } \\
\text { Poor Families }\end{array}$ & $\begin{array}{c}\text { Number of } \\
\text { Non-Poor Families }\end{array}$ & $\begin{array}{c}\text { Percentage of } \\
\text { Poor Families }\end{array}$ \\
\hline Asri Jaya & 271 & 544 & $33.25 \%$ \\
\hline Bauran & 67 & 288 & $18.87 \%$ \\
\hline Cawanan & 382 & 108 & $77.95 \%$ \\
\hline
\end{tabular}

Table B: Family data

\begin{tabular}{l|l}
\hline Name of Family & Poverty Status \\
\hline Amin & Poor \\
\hline Bobby & Not Poor \\
\hline Charles & Not Poor \\
\hline Dody & Poor \\
\hline$\ldots \ldots .$. & $\ldots \ldots$. \\
\hline
\end{tabular}

Table $\mathrm{A}$ is the aggregation of data in Table B. To update data in Table A, which is in aggregated form, is difficult because it demands survey on all of the data. To illustrate the point: in Asri Jaya, the number of poor families is 271; however, we have no idea which individual families belong to the poor category. Only another survey can tell.

On the other hand, updating data in Table B is easier because it contains single data per family. Changing data on one family automatically modifies the aggregate data. As an illustration, the Amin family climb up the economic ladder (e.g. the head of the family has a better paying job), hence, the family stops being categorised as 'Poor' and automatically referred to as 'Not Poor' modifying the aggregate data of poor families.

When data management operations are carried out on the table that contains single data representation (such as Table B), it is easier to update data and get a better understanding of the data, compared to updating on aggregated data (such as in Table A). With the use of a computer to conduct aggregation, updating is made easier. Changing single data automatically translates into modified aggregated data.

\section{Observed change}

Data revolution implementation produced some observed changes affecting the government and citizens in Bojonegoro district. It covers changes in the way they view and judge the quality of their data, changes in the way they use the data, and changes in the form of collaboration between the government and CSOs regarding data provision and data utilisation. 
Some local government staff were aware of the data quality that they had and desired to improve the quality of their agencies' data and make it more open. For example, the local planning agency realised that their data on poverty was inadequate to address the real poverty challenges due to lack of detail about data on poor families (which ones are poor) and the slow update of the data. In contrast, data from the data revolution addresses those issues and is more suitable to their needs.

Local development actors (local government, village government, CSOs) started to have new insights about the utilisation of data. They now saw that the data is vital in measuring local development accomplishments as well as in improving targeted social assistance programmes in development. All of these have been possible due to the data revolution with its single (disaggregated) and open data.

There is a desire of the local government to collaborate with CSOs to improve data provision. The local government viewed the CSOs as capable in helping to provide disaggregated data. With this new government approach, institutions working to empower citizens (especially CSOs) are strengthened because of the opportunities presented by their involvement in data provision.

In our observation, it was the implementation of data revolution that allowed those changes to take place. We observed that the contribution of data revolution on those changes was as follows:

Figure 5. Contribution of the data revolution in stimulating data use

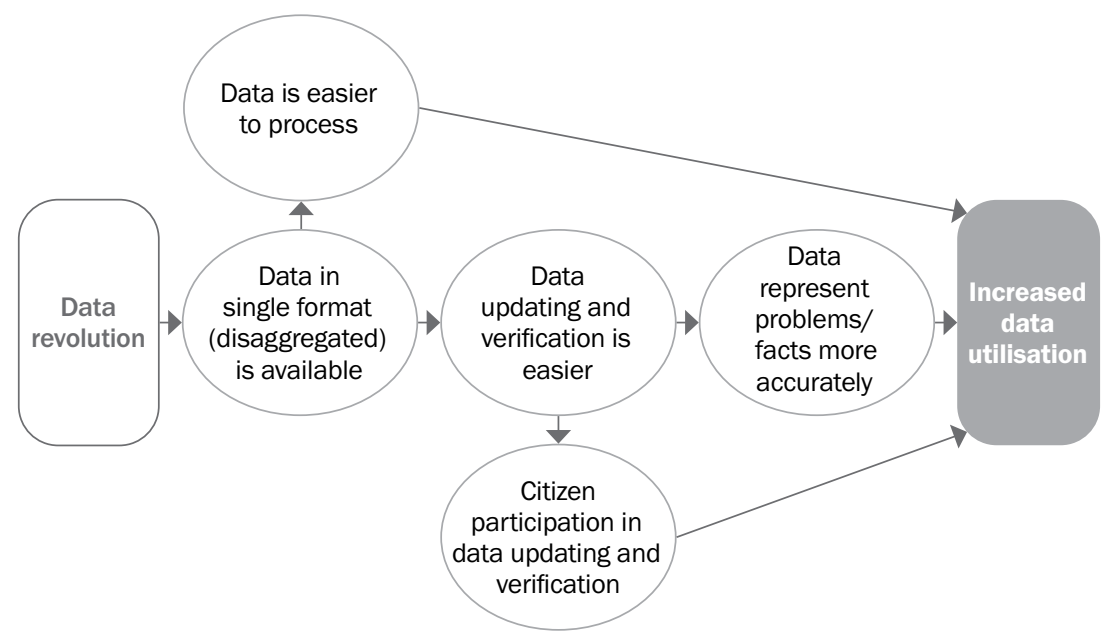

- Some local government staff of Bojonegoro welcomed the second process of open data implementation (data revolution) as they saw the possibility and feasibility of collecting and processing single data. Data in this 
format can be used and processed into up to date information that the government needs. This inspired them to initiate a new treatment of their agencies' data with the same approach.

- Some lower level government officials (village level) found that the data revolution allowed gave them the opportunity to manage data easier, especially in data updating and verification. The single data made it possible to update and verify the data, which is something the officials needed. ${ }^{12}$

- The CSOs that we met also looked at the single data provided by data revolution as valuable. Owing to its updated nature, the data system allows for participation and makes transparency more useful. Some CSOs see that such data can be used to contribute to achieving development goals, for example, the data can be used for the monitoring of SDG accomplishments and for the monitoring of procurement contracts.

- The data revolution processes, in which there are components of significant participation by citizens/communities in the updating and verification of data, helped facilitate government-CSO collaboration. The experience of data revolution implementation resulted in a desire to maintain collaboration between government and CSOs in data-related work on a continual basis.

\section{Potential for follow-up on the changes}

The observed changes mentioned above have the potential to strengthen efforts toward reaching the intended impact of open data initiatives from the very beginning - data openness and utilisation of the opened data.

Figure 6. Expected scenario (based on changes already taking place)

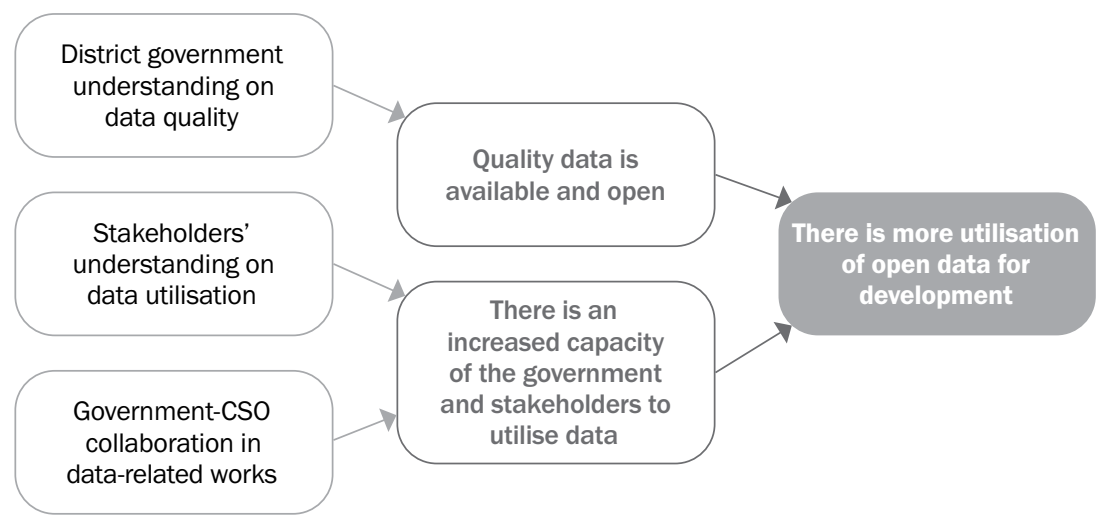

12 Village officials are responsible for targeted social assistance programmes funded by the upper level governments. The accurate, updated, and valid (verified) data are vital for them. 
At the time of writing of this chapter, data revolution implementation is still ongoing, measuring impact/results at this point may be inapplicable or at least premature. What is presented as findings are the changes already taking place. Figure 6 above shows the expectations - a kind of future scenario - resulting from those changes. It is expected that the provision of open and good quality data becomes the agenda of the local government along with their increased understanding of the importance of data quality for development. In addition, the improved understanding of the stakeholders on the benefits of open data and the collaboration between government and CSOs in data-related works is expected to lead to or have implication in the form of the increased capacity of the government and other stakeholders in data utilisation.

\section{Conclusion}

The initial open data implementation in Bojonegoro district was carried out with a high level of transparency. Nevertheless, the expected level of data usage by the target groups remained low. This was inseparable from some disconnections that beset the implementation of the initiative. Our action research shows that the disconnections were caused by incompatibility of available data with the needs of the prospective data users; the quality of available data falling short of the quality required by the data users; and the lack of capacity of the data users in utilising the data.

This kind of phenomenon is common in ICT projects for development around the world, especially those in developing countries, where lack of data quality and low human capacity to initiate demand of governance reinforce each other. Diniz et al. (2014) noted that various studies locate the 'failures' of ICT projects at the gap between the need of the end-users and the perception of the ICT designers. They proposed an approach that emphasises the modification of the context, as it is 'malleable' in relation to technology design and use. They considered that 'users might modify not the technology, but the social, organisational, political, economic, cultural, or other context surrounding use' (Diniz et al. 2014: 16).

We stand to differ here. We consider both the technology and the context as shaping each other. In terms of technology, the data format matters. In relation to the context, Bojonegoro district introduced many changes (modifying the context) to allow for the implementation of ICT to support its Open Government Partnership goals.

That's why the data quality and the suitability of the data are inseparable from the format of data representation and how the data is treated in the system. The absence of a data representation format in the form of single data (because what is stored is only those in aggregate data format) led to data that is inflexible, difficult to update and hard to verify. Such a situation led the data users to consider and perceive the data as of low quality and less suitable for their needs. 
The situation is considered as 'gaps' which must be closed with other initiatives or innovations. The initiative/innovation that the Bojonegoro district government took - referred to as data revolution - was an open data initiative that involved data-related works using single data and employing citizen participation in data collection. In this case, data revolution with its main feature of disaggregated data, use of IT applications, and the involvement of public participation in datarelated works, were carried out to close the gaps.

Even though it is still too early to tell the impact of the implementation of the 'close the gap' solution, there have been promising changes in local government bureaucracy. For example, we found a new understanding and awareness from district government officials regarding data quality, the desire to utilise the opened data (as long as the data quality is improved), and there have been collaborations with CSOs in conducting data-related works.

In particular, we want to highlight the collaboration between CSOs and local governments in data-related works. The collaboration took place before and after the implementation of the data revolution initiative. CSOs in this case play a role in contributing to the conception of ideas and in implementation processes. At the time of the conception of the idea of the data revolution, CSOs took the role of conducting studies and formulating ideas for obtaining a data revolution model suitable for Bojonegoro district. While in the implementation phase, CSOs played a role in facilitating the participation of citizens in the data collection process.

The implementation of the data revolution initiative (or open data phase 2) is expected to have a direct contribution to the beneficiaries of local development - the citizens. But at this moment, it is still too early to say that the changes have reached that level. Nevertheless, there have been significant changes at the level of district government officials whose daily jobs are strongly related to local development data. This open data initiative allowed work processes using data to become easier, more democratic and more direct. Previously, if a government agency needed data from other agencies, then the process could take a long time, having to go through a long bureaucracy and with uncertainty about data quality. This open data initiative makes data from various agencies available on the web and can be downloaded immediately, although there are still quality problems as mentioned earlier. In addition, the introduction of a single data concept has made a difference in the way they perceive data quality.

In general, the lesson that can be drawn from the action research carried out by Sinergantara is that the availability of open data (in a government) does not always translate to the automatic benefit of open data access. To guarantee that open data does bring benefits, it is necessary to ensure data quality sufficiency (e.g. the data must be up to date and complete) and that the data can easily be processed to suit the needs of prospective data users. That is why it is crucial to take into account the format/representation of the data.

In particular, the lesson is related to data format/representation. The single data format introduced in phase 2 of open data in Bojonegoro (data 
revolution) showed a strong prospect to be followed up on. This single data format had raised the interest of development actors in the district, especially the government and CSOs.

\section{REFERENCES}

Diniz EH, Bailey DE \& Sholler D (2014) Achieving ICT4D project success by altering context, not technology. Information Technologies E International Development 10(4): 15-29

Fox J (2016) Scaling accountability through vertically integrated civil society monitoring and advocacy. Making All Voices Count Working Paper. Brighton, UK: IDS

Gaventa J (2006) Finding the spaces for change: A power analysis. IDS Bulletin 37(6): 23-33

Kemmis S, McTaggart R \& Nixon R (2014) The Action Research Planner: Doing Critical Participatory Action Research. London: Springer

Kindon S, Pain R \& Kesby M (eds) (2007) Participatory Action Research Approaches and Methods: Connecting People, Participation and Place. Abingdon, Oxfordshire: Routledge

Maail AG (2017) The relational impact of open data intermediation: Experience from Indonesia and the Philippines. In: F van Schalkwyk, S Verhulst, G Magalhães, J Pane \& J Walker (eds) The Social Dynamics of Open Data. Cape Town: African Minds. pp. $153-166$

McNiff J \& Whitehead J (2002). Action research: Principles and practice. London: Routledge

Open ePolicy Group (2005) Roadmap for open ICT ecosystems. https://cyber.harvard. edu/epolicy/roadmap.pdf

Orlikowski WJ (1992) The duality of technology: Rethinking the concept of technology in organizations. Organization Science 3(3): 398-427

Redman TC (2008) Data Driven: Profiting from Your Most Important Business Asset. Boston: Harvard Business Press

Roberts T \& Hernandez K (2017) The techno-centric gaze: Incorporating citizen participation technologies into participatory governance processes in the Philippines. Making All Voices Count Research Report. Brighton: IDS

Sachs JD (2015a, 6 May) Data for development. Project Syndicate. https://www.projectsyndicate.org/commentary/sustainable-development-data-by-jeffrey-d-sachs-2015-05

Sachs JD et al. (2015b, 18 September) The data revolution for sustainable development. Project Syndicate. https://www.project-syndicate.org/commentary/sdgs-datacollection-by-jeffrey-d-sachs-et-al-2015-09

Smith M \& Laurent E (2010) Open ICT ecosystems transforming the developing world. Information Technologies and International Development 6(1): 65-71

Srimarga IC, Wibowo A \& Aisah S (2017) Efektifitas Pemanfaatan Teknologi Informasi Dan Komunikasi untuk Memperkuat Transparansi, Akuntabilitas dan Partisipasi serta Keselarasan Interaksinya dengan Platform Offline. Unpublished MAVC Learning Paper. Jakarta: Sinergantara

Yuliar S (2009) Tata Kelola Teknologi: PerspektifTeori Jaringan Aktor. Bandung: Bandung Institute of Technology (ITB) Press 